SAND76-8054

Unlimited Release

$\therefore$

\title{
Plasma-Sprayed Tantalum/Alumina Cermets
}

C. M. Kramer

Prepared by Sandia Laboratories, Albuquerque, New Mexico 87115

and Livermore, California 94550 for the United States Department

of Energy under Contract AT (29-1)-789.

Printed December 1977

When printing a copy of any digitized SAND Report, you are required to update the markings to current standards. 
Issued by Sandia Laboratories, operated for the United States Department of Energy by Sandia Corporation.

\section{NOTICE}

This report was prepared as an account of work sponsored by the United States Government. Neither the United States nor the United States Department of Energy, nor any of their employees, nor any of their contractors, subcontractors, or their employees, makes any warranty, express or implied, or assumes any legal liability or responsibility for the accuracy, completeness or usefulness of any information, apparatus, product or process disclosed, or represents that its use would not infringe privately owned rights. 
SAND76-8054

Unlimited Release

Printed December 1977

PLASMA -SPRAYED TANTALUM/ALUMINA CERMETS

C. M. Kramer

Exploratory Chemistry Division 8313

Sandia Laboratories

Livermore, California 94550

\begin{abstract}
Cermets of tantalum and alumina were fabricated by plasma spraying, with the amount of alumina varied from 0 to 65 percent (by volume). Each of four compositions was then measured for tensile strength, elastic modulus, and coefficient of thermal expansion. In general, strength and strain to failure decreased with increasing alumina content: $62 \mathrm{MPa}$ for 100 percent $\mathrm{Ta}$ to $19 \mathrm{MPa}$ for $35 \mathrm{v} \% \mathrm{Ta}$. A maximum of 0.1 percent strain was observed for the sprayed 100 percent Ta specimens. The coefficient of thermal expansion measured for the pure Ta was $6.2\left(10^{-6}\right) / \mathrm{K}$.
\end{abstract}




\section{ACKNOWLEDGMENTS}

I wish to thank Pete Oliver and Morris Mote of Sandia Laboratories, Livermore, and L. Abbatiello of Union Carbide for their assistance and encouragement. 


\section{CONTENTS}

Page

Introduction

Plasma Spraying Technique

Experimental Procedure

Powder Character

16

Fabrication

18

Testing

20

Results

23

Conclusions

References 


\section{ILLUSTRATIONS}

Figure

Page

1. Plasma Spray Gun 15

2. Starting Powders of (a) Alumina and (b) Tantalum for Plasma Spraying Cermets

3. Elastic Modulus of Plasma-Sprayed $\mathrm{Ta} / \mathrm{Al}_{2} \mathrm{O}_{3}$ Cermets

4. Ultimate Tensile Strength of Plasma-Sprayed Ta/ $\mathrm{Al}_{2} \mathrm{O}_{3}$

5. Effect of Increasing Helium in Arc Gas While Plasma Spraying Coarse Tantalum Powder

6. Increase in Deposition Efficiency as a Result of Increasing Helium in the Arc Gas During Plasma Spraying Coarse Tantalum Powder

7. Cross-Section Photomicrographs of the Four Samples of $\mathrm{Ta} / \mathrm{Al}_{2} \mathrm{O}_{3}$ Cermets

8. Fracture Surfaces of Cermets of $\mathrm{Ta} / \mathrm{Al}_{2} \mathrm{O}_{3}$ Hlustrating Intra- and Inter-particle Fracture in Both Phases 


\section{TABLES}

Table

Page

I. Conditions Used For Plasma Spraying Cermets 19

II. Test Results $\quad 26$

III. Mechanical Properties of Plasma-Sprayed Tantalum/. Alumina Cermets

IV. Mechanical Properties of Samples From the Literature and This Study

V. Normalized Mechanical Properties of $\mathrm{Ta} / \mathrm{Al}_{2} \mathrm{O}_{3}$ Cermets 


\section{PLASMA-SPRAYED TANTALUM/ALUMINA CERMETS}

\section{Introduction}

Ceramic/metal combinations (cermets) are of interest to materials engineers because a cermet may exhibit desirable properties of both the metal and the ceramic of which it is composed; for instance, increased hardness, wear resistance, and high temperature strength. The combination of these characteristics on a microscopic scale would be very valuable in an application such as a heat shield. Here the ceramic would absorb the heat from the thermally conductive metal because the relationship of the two materials would be intimate but distinct. Plasma spraying offers a unique opportunity to fabricate such an intimate, but distinct, mixture of materials which would react chemically if combined by means of the conventional powder material techniques of sintering and hot pressing.

This paper describes an experiment in which cermets of tantalum and alumina were fabricated by plasma spraying, removed from the substrate, and measured to determine tensile strength, elastic modulus, and coefficient of thermal expansion as a function of composition.

\section{Plasma Spraying Technique}

The principle of plasma spraying is to melt powder particles and accelerate them onto a substrate. An electric arc is used as the heat source 
to generate a partially ionized gas stream. A cross section of a plasma spray gun (Figure 1) shows the anode and the cathode, which have different voltages. The arc gas ionizes in the cavity between the electrodes, and the flame quench device reduces the heat flux to the substrate by diverting the plasma flame with a stream of argon. The operating fluid (in this study He and Ar were used) transfers heat to the powders as the gaseous ions and electrons recombine. The temperature of the particles is a function of the thermal properties of the material, the powder particle mass and shape, the heat transfer characteristics of the plasma stream, and the dwell time in the stream. ${ }^{1}$ In previous studies, experimenters have observed temperatures in excess of $20,000 \mathrm{~K}$ in the gas, 2,3 and the heat transfer of the plasma has been sufficient to melt even refractory materials. 4

The character of the plasma-sprayed deposit may be widely varied, depending upon the powder and spray conditions used. ${ }^{1}$ The porosity, strength, and phase distribution are sensitive to the plasma gun design, the spraying parameters, and the properties of the powder. In one study the spraying conditions were correlated with the coefficient of friction of the resulting deposit. ${ }^{1}$ Other studies of plasma spraying have shown that the helium in the plasma arc gas increases the heat transfer characteristics with respect to the powder ${ }^{5}$ and that a size fraction of 10 to $70 \mu \mathrm{m}$ particles is appropriate. ${ }^{6}$ Larger particles are not sufficiently molten, and smaller particles tend to vaporize. Although plasma spraying is a high-temperature process, materials with vastly different melting points can be mixed and co-sprayed with little interaction in the plasma stream. 


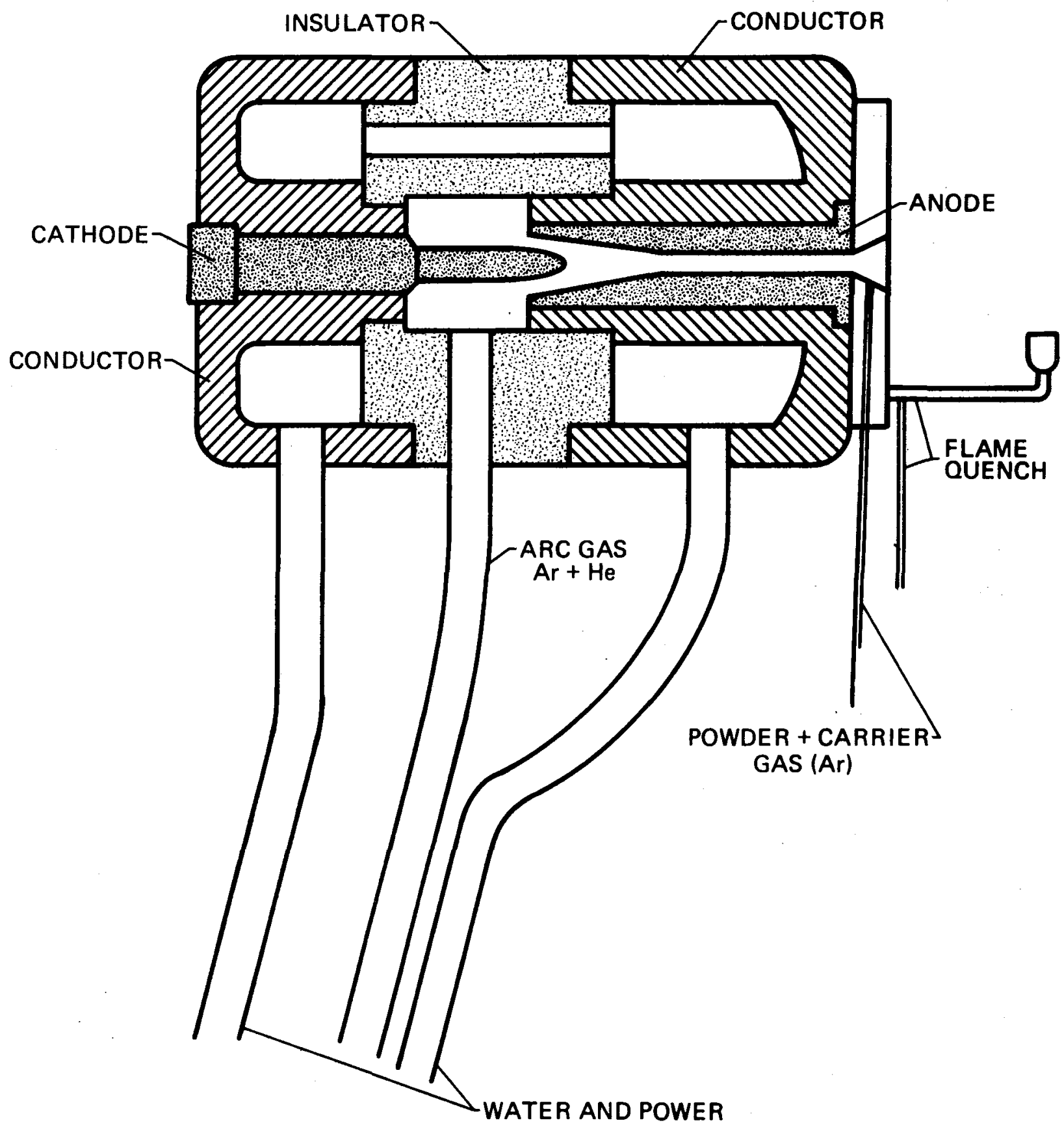

Figure 1. Plasma Spray Gun 
Because the plasma can be an inert gas rather than the reactive gases of a flame, oxidizable and pyrophoric materials can be sprayed with minimum contamination. ${ }^{7}$ When necessary, the whole operation can be enclosed in a chamber filled with an inert gas to further minimize contamination; such enclosures also permit the spraying of toxic materials.

The optimum parameters for this study were chosen from preliminary experiments on the basis of spraying efficiency, which refers to the amount of powder deposited compared to the amount fed through the plasma spray gun.

\section{Experimental Procedure}

\section{Powder Character}

Buehler 400 grit alumina and tantalum powder supplied by Union Carbide were used for the cermet fabrication. The alumina was a fine, closely sized powder, with 85 percent in the range of 10 to $37 \mu \mathrm{m}$, as determined by precision sieve analysis. The surface area of the alumina was $0.340 \mathrm{~m}^{2} / \mathrm{g}$ or $4.4 \mu \mathrm{m}$ equivalent spherical diameter. Figure $2 \mathrm{a}$ is a scanning electron photomicrograph illustrating the irregularly shaped grains and adherent fines of the alumina. X-ray analysis showed that the powder was mainly alpha-alumina; however, two other minor phases, the $\gamma-\mathrm{Al}_{2} \mathrm{O}_{3}$ phase and one containing silica and alumina, were present. The powder was 95 wt $\%$ alumina, did not flow well, and had an apparent density of 35 percent of theoretical. 


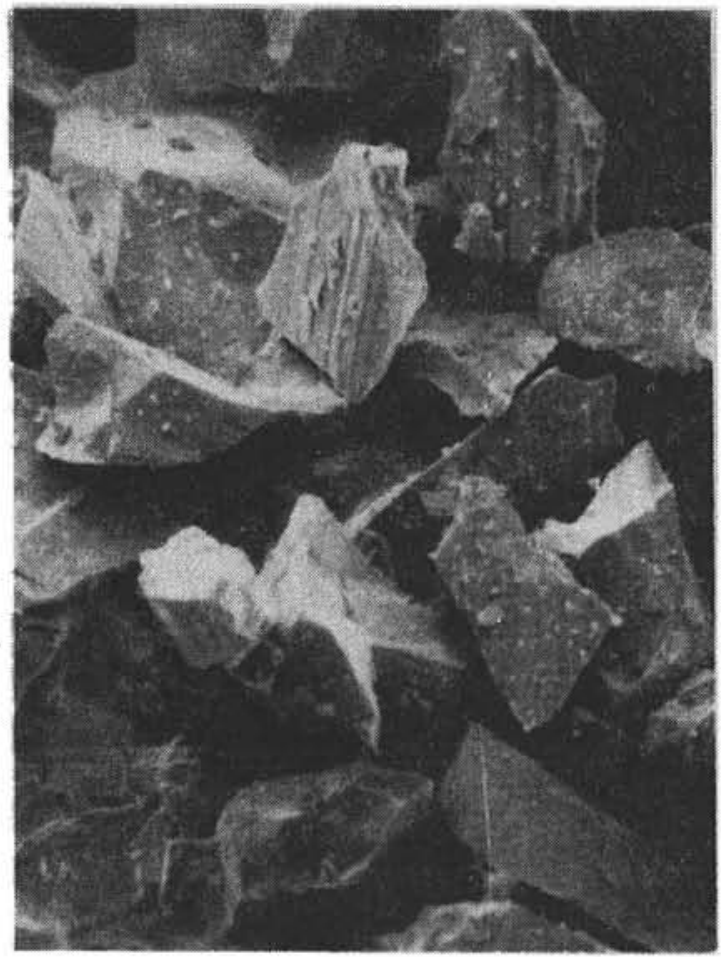

a

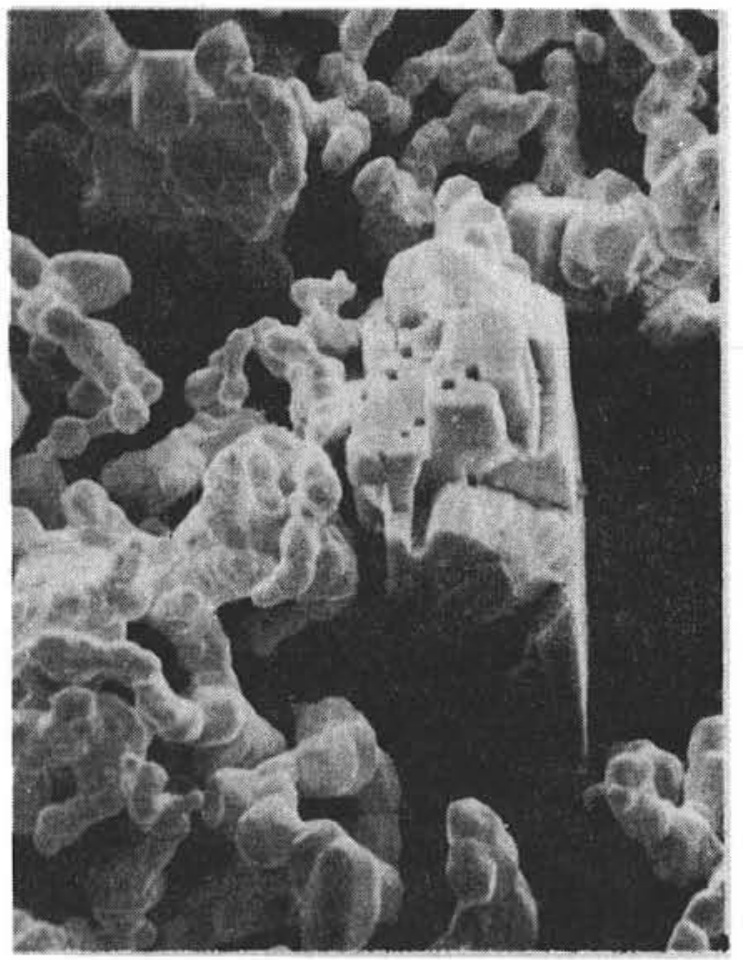

$\mathrm{b}$ $30 \mu \mathrm{m}$

Figure 2. Starting Powders of (a) Alumina and (b) Tantalum for Plasma Spraying Cermets 
The tantalum used was pure and flowed very easily, and 96 percent of the powder was 10 to $34 \mu \mathrm{m}$ in size. As shown in Figure $2 \mathrm{~b}$, the tantalum was composed of branched and faceted chains. The apparent density of the powder was 19 percent of theoretical and much lower than that of the alumina. Surface area of the tantalum was $0.09 \mathrm{~m}^{2} / \mathrm{g}$ or $4.0 \mu \mathrm{m}$ equivalent spherical diameter.

The apparent particle sizes of the metal and ceramic powders were similar; however, their morphologies varied greatly.

\section{$\underline{\text { Fabrication }}$}

Three different compositions of tantalum and alumina were mixed in a V-blender. The mixtures were denoted 51,81 , and 95, indicating the weight percentage of tantalum in each. A fourth powder was composed of 100 percent tantalum. Prior to spraying, the plasma spray powder feeder was calibrated for each mixture.

The plasma gun used for spraying the cermets was a modified Plasmadyne SG-1B, mounted for remote control in an argon atmosphere glove box. The powders were injected externally at an angle of 13 degrees. Specific spraying conditions are listed in Table I. The major difference between the spraying conditions for the pure tantalum and those for the cermets was the arc gas He/Ar ratio. Since the flame quench attachment diverted the low-density alumina, it was used only with the 100 percent tantalum. Samples of each composition were sprayed on rectangular 
TABLE I

CONDITIONS USED FOR PLASMA SPRAYING CERMETS

\begin{tabular}{|c|c|c|c|c|c|c|}
\hline $\begin{array}{l}\text { Cermet } \\
\text { Mixture } \\
(w t \% \mathrm{Ta}) \\
\end{array}$ & $\begin{array}{l}\text { Arc Gas } \\
\text { Mixture } \\
\end{array}$ & $\begin{array}{c}\text { Amperage } \\
\text { (A) }\end{array}$ & $\begin{array}{c}\text { Stand-Off } \\
(\mathrm{cm})\end{array}$ & $\begin{array}{c}\text { Powder Gas } \\
(\ell / \mathrm{hr})\end{array}$ & $\begin{array}{c}\text { Feed Rate } \\
(\mathrm{g} / \mathrm{min})\end{array}$ & $\begin{array}{l}\text { Flame } \\
\text { Quench }\end{array}$ \\
\hline 100 & $50 \mathrm{He} / 50 \mathrm{Ar}$ & 400 & 9 & 200 & 20 & yes \\
\hline 95 & $37 \mathrm{He} / 63 \mathrm{Ar}$ & 400 & 9 & 200 & 20 & no \\
\hline 81 & $37 \mathrm{He} / 63 \mathrm{Ar}$ & 400 & 9 & 200 & 10 & no \\
\hline 51 & $37 \mathrm{He} / 63 \mathrm{Ar}$ & 400 & 9 & 200 & 7 & no \\
\hline
\end{tabular}


prisms $(5 \times 5 \times 15 \mathrm{~cm})$ of polished aluminum rotating at $100 \mathrm{rpm}$, with the gun traversing the length of the rotating substrate. Because of the great difference between thermal expansion of the aluminum and that of the deposit, the sprayed cermet could be easily removed without removing any substrate.

\section{Testing}

Samples of each composition were analyzed by wet chemistry, mounted for metallographic examination, tested for porosity and thermal expansion, scanned by X-rays, and fabricated into tensile bars. To measure the coefficient of thermal expansion with a low force dilatometer the samples were heated at $20 \mathrm{~K} / \mathrm{min}$ to $1000^{\circ} \mathrm{C}$ in a gettered argon atmosphere.

Each combination of tantalum and alumina was very friable and had to be machined by electro-discharge machining or diamond grinding. The tensile bars were 0.8 to $1.8 \mathrm{~mm}$ thick and had a gauge section $1.25 \mathrm{~cm}$ wide by $2.5 \mathrm{~cm}$ long. The ends of the samples were cast in plastic with strips of aluminum to facilitate gripping the tensile bar in the Instron testing machine. A $1.25-\mathrm{cm}$ extensometer monitored the strain as the samples were pulled at the rate of $0.13 \mathrm{~mm} / \mathrm{min}$. Specimens were repeatedly loaded and unloaded when possible, and the elastic modulus (E) and ultimate tensile strength (UTS) were computed for each specimen. The first loading curve was discarded in the computation of moduli, since it was consistently lower than successive measurements and included adjustment of the specimens in the grips. The measured elastic moduli for each composition are graphically illustrated in Figure 3 and the tensile strengths are illustrated in Figure 4. 


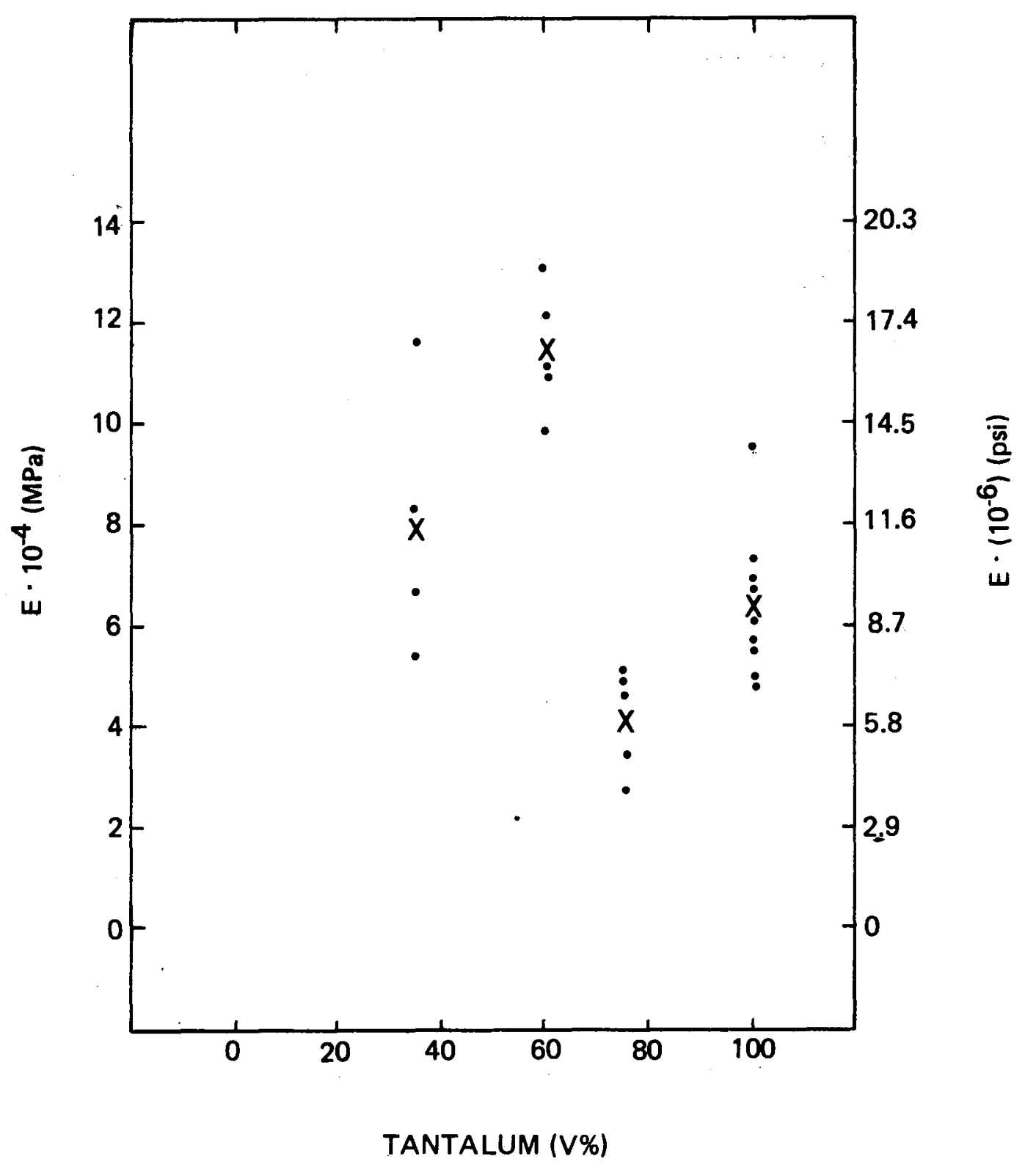

Figure 3. Elastic Modulus of Plasma-Sprayed $\mathrm{Ta} / \mathrm{Al}_{2} \mathrm{O}_{3}$ Cermets 


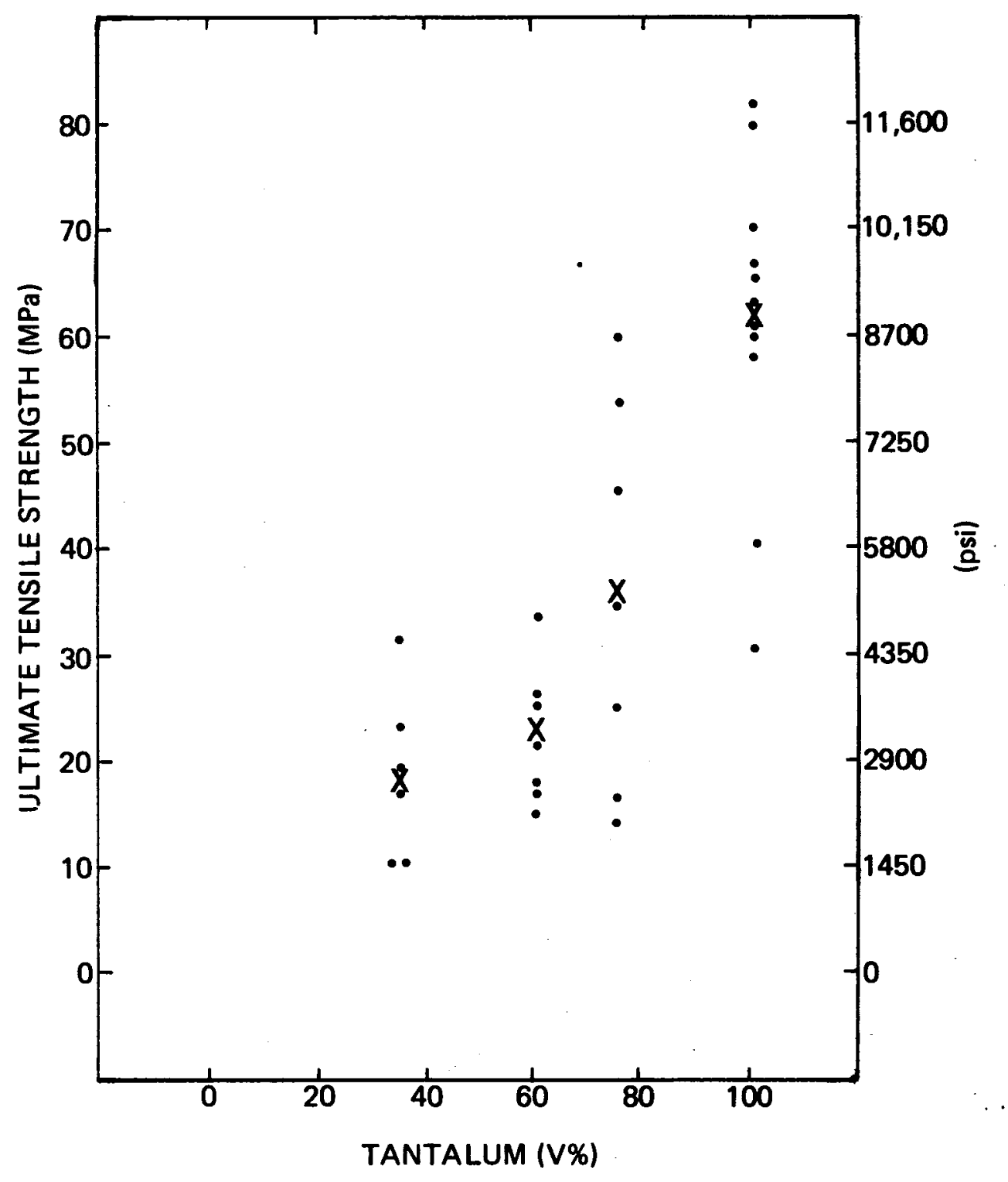

Figure 4. Ultimate Tensile Strength of Plasma-Sprayed $\mathrm{Ta} / \mathrm{Al}_{2} \mathrm{O}_{3}$ Cermets 


\section{Results}

Before the actual tests were run, some preliminary studies were conducted on a coarse grade of tantalum powder (70 to $100 \mu \mathrm{m})$ to determine the effect of various spray parameters. The most dramatic effect was seen when the percentage of helium in the arc gas was changed, as illustrated in Figures 5 and 6. The degree of melting, the density, and the deposition efficiency increased markedly as helium was added to the ionized gas stream. The sequence of micrographs in Figure 5 illustrates the transition of the coarse $\mathrm{Ta}$ to a laminar structure as more helium was added to the plasma. The deposition efficiency of the alumina was highest at a He/Ar ratio of $37 / 63$, and the deposition of the finer Ta was not much decreased at spray conditions of 37 percent He. Therefore, during the experiment, the cermets were sprayed at an arc gas ratio of $37 \mathrm{He} / 63 \mathrm{Ar}$, while the pure Ta was sprayed at $50 \mathrm{He} / 50 \mathrm{Ar}$.

Results of the chemistry, X-ray, and density tests on the four samples are summarized in Table II. The volume percent of the metal, ceramic, and pore phases was substantiated by cross sections analyzed using the Quantimet, a computerized metallographic tool. Figure 7 shows crosssection photomicrographs for each composition. The mechanical properties, which were measured perpendicular to the spraying direction, are summarized in Table III.

The laminar microstructures illustrated in Figure 7 contrast with the starting powder morphology. Melting and spreading is evident for each 


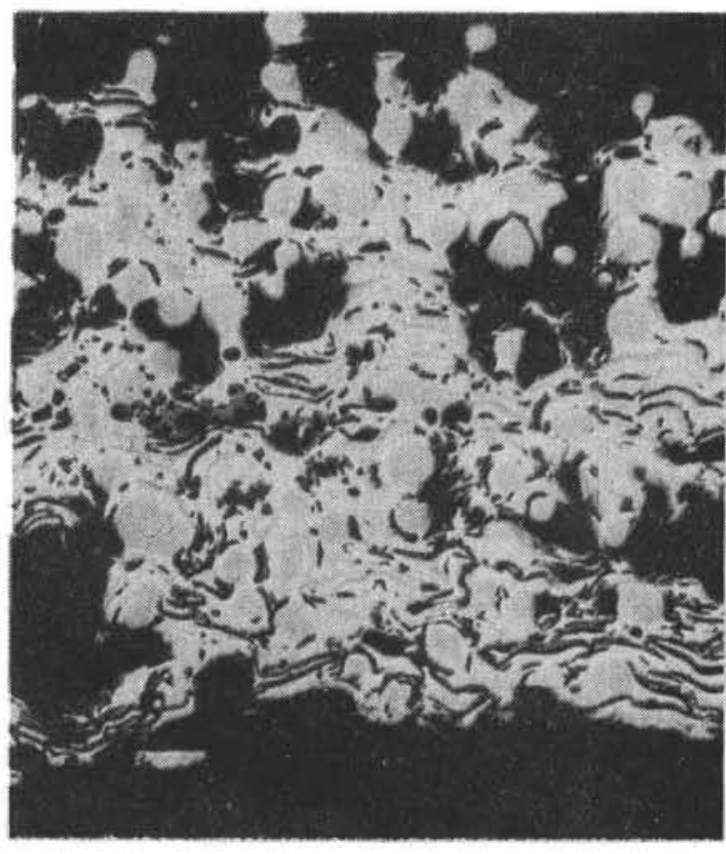

$100 \% \mathrm{Ar} / \mathrm{O} \% \mathrm{He}$ arc gas content

$200 \mu \mathrm{m}$

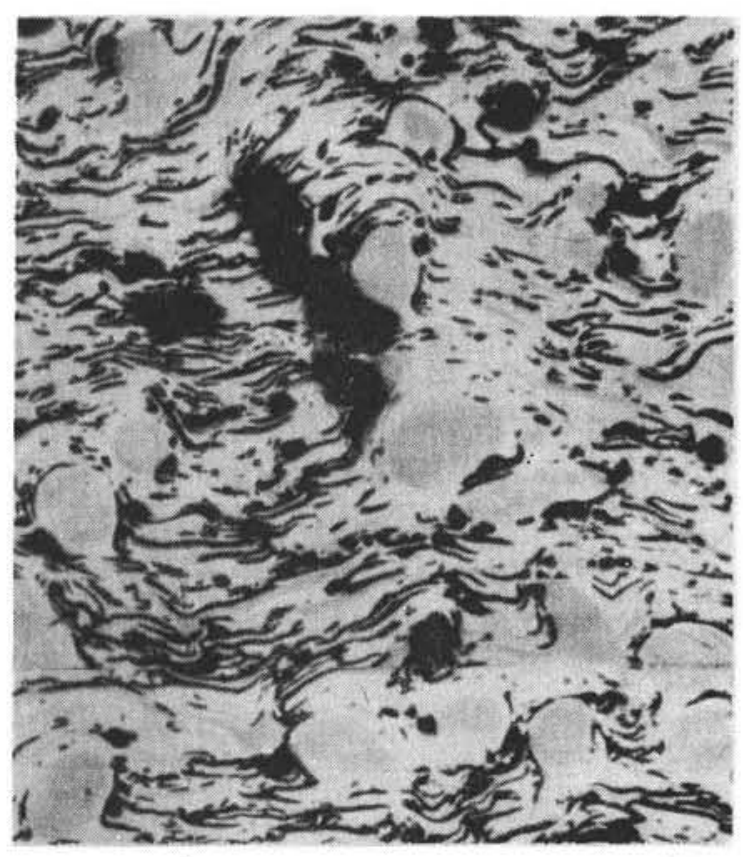

$85 \% \mathrm{Ar} / 15 \% \mathrm{He}$

$200 \mu \mathrm{m}$

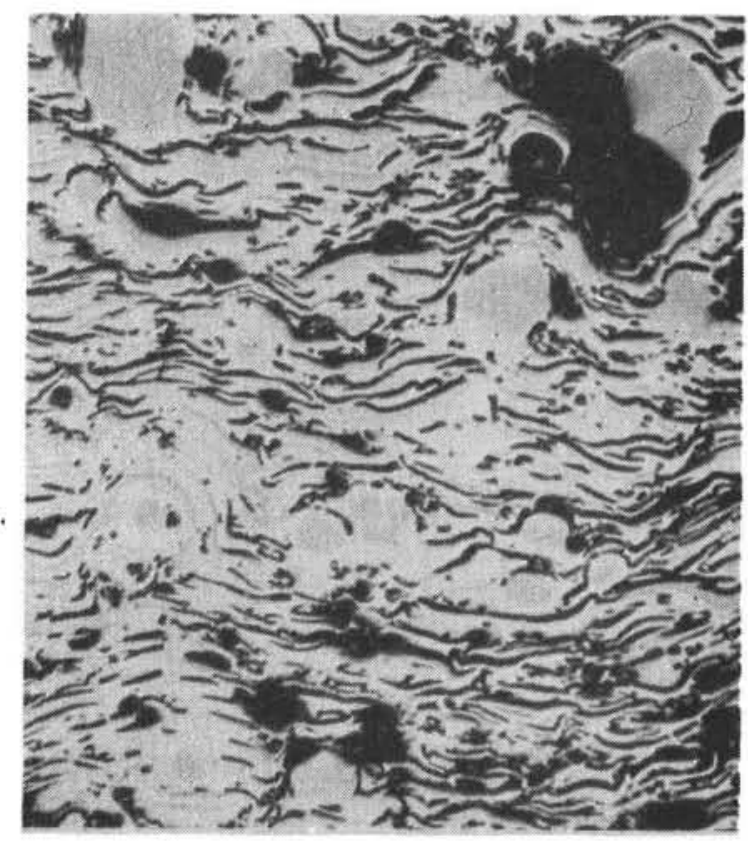

$37 \% \mathrm{Ar} / 63 \% \mathrm{He}$

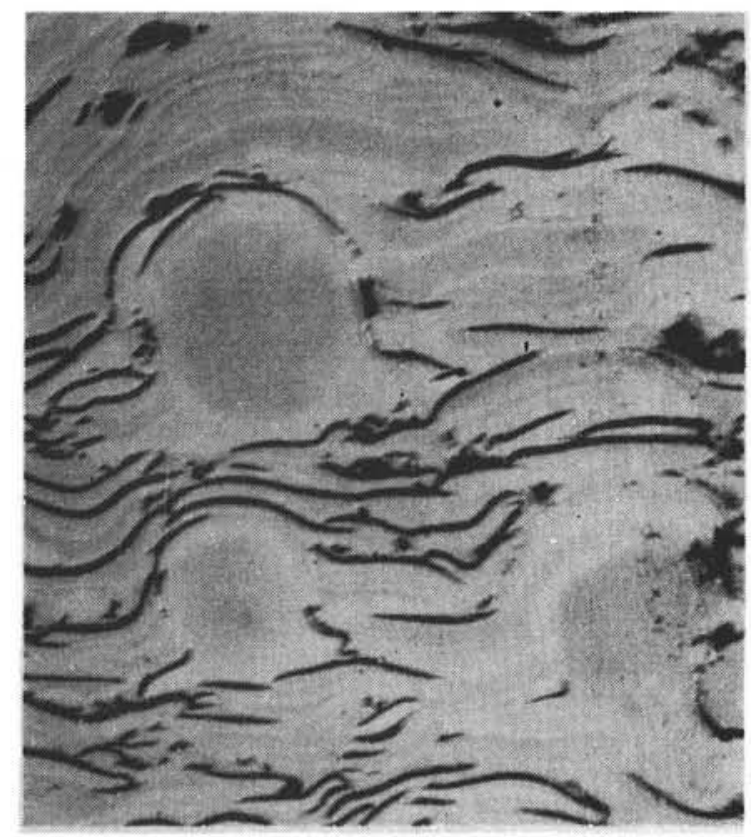

$50 \% \mathrm{Ar} / 50 \% \mathrm{He}$

$100 \mu \mathrm{m}$

Figure 5. Effect of Increasing Helium in Arc Gas While Plasma Spraying Coarse Tantalum Powder 


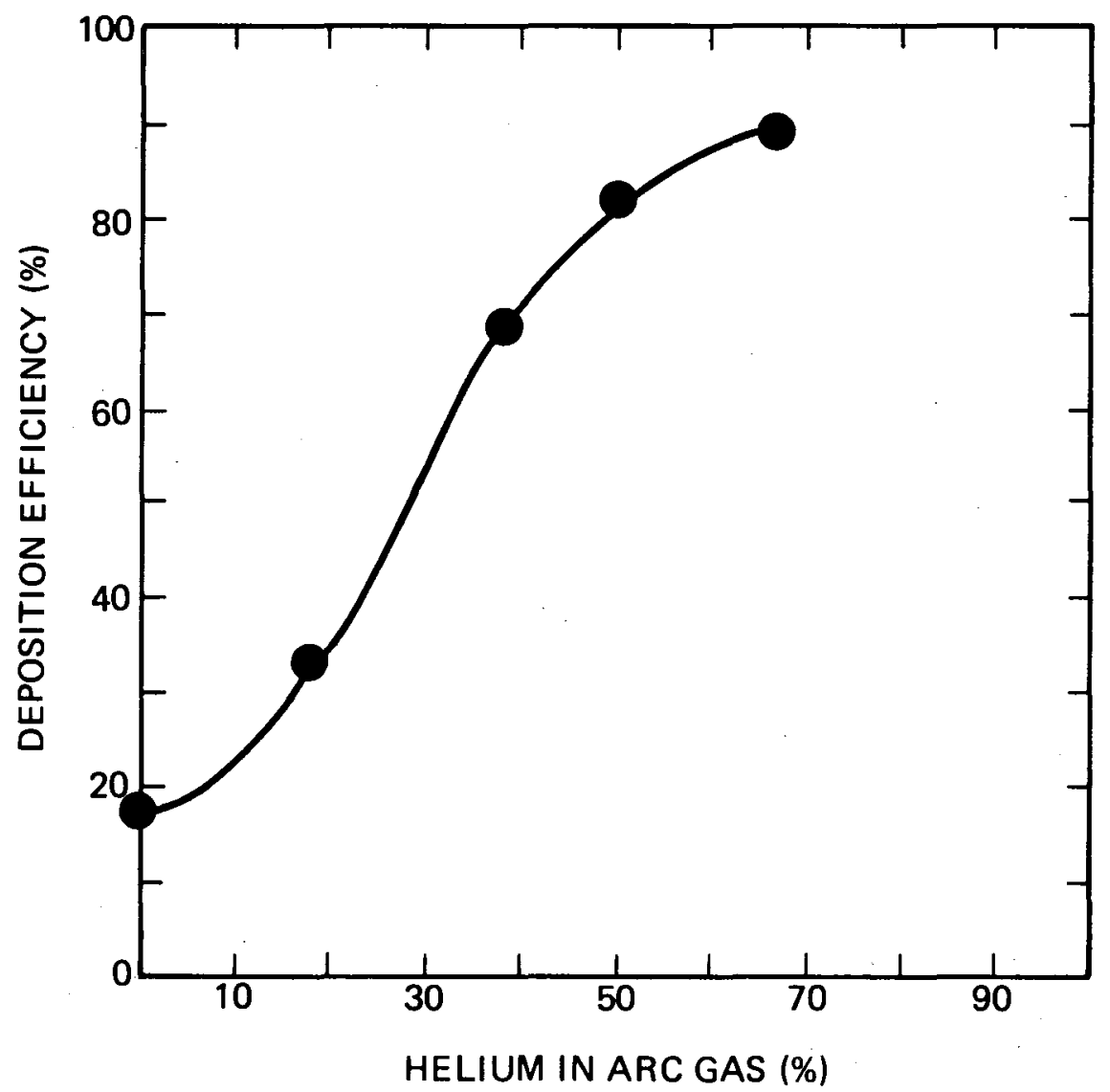

Figure 6. Increase in Deposition Efficiency as a Result of Increasing Helium in the Arc Gas During Plasma Spraying Coarse Tantalum Powder 
TABLE II

TEST RESULTS

\begin{tabular}{|c|c|c|c|c|c|c|c|}
\hline \multirow[b]{2}{*}{ Mixture } & \multirow{2}{*}{$\begin{array}{c}\mathrm{Ta} * \\
(\mathrm{wt} \%)\end{array}$} & \multirow{2}{*}{$\begin{array}{c}\mathrm{Ta}^{\dagger} \\
(\mathrm{v} \%)\end{array}$} & \multicolumn{4}{|c|}{ Phases Detected by X-Ray ${ }^{\infty}$} & \multirow{2}{*}{$\begin{array}{l}\mathrm{P}^{+t} \\
(\%)\end{array}$} \\
\hline & & & $\mathrm{Ta}_{2} \mathrm{O}_{5}$ *决 & $\alpha \mathrm{Al}_{2} \mathrm{O}_{3}$ & $\gamma \mathrm{Al}_{2} \mathrm{O}_{3}$ & $\overline{\mathrm{Ta}}$ & \\
\hline \multirow[t]{2}{*}{100} & - & -- & $3-U$ & -- & -- & 1 & 8 \\
\hline & & & $7-\mathrm{T}$ & -- & -- & & \\
\hline \multirow[t]{2}{*}{95} & 93 & 75 & $1-U$ & -- & $6-\mathrm{T}$ & 2 & 10 \\
\hline & & & -- & $4-T$ & $5-U$ & & \\
\hline \multirow[t]{2}{*}{81} & 86 & 60 & $3-U$ & -- & $4-U$ & 3 & 7 \\
\hline & & & $6-\mathrm{T}$ & $2-\mathrm{T}$ & $3-T$ & & \\
\hline \multirow[t]{2}{*}{51} & 56 & 35 & $5-U$ & $3-U$ & $2-U$ & 4 & 10 \\
\hline & & & $2-T$ & $1-T$ & $1-\mathrm{T}$ & & \\
\hline
\end{tabular}

*By wet chemistry

†Calculated from chemistry and Quantimet areal analysis

**Minor phase compared to Ta

$\dagger$ †orosity from $\mathrm{Hg}$ porosimetry and Quantimet areal analysis

${ }^{\infty}$ In decreasing order in any column (if detected), $\mathrm{U}=$ underside, $\mathrm{T}=$ top side 
TABLE III

MECHANICAL PROPERTIES OF PLASMA-SPRAYED TANTALUM/ALUMINA CERMETS

\begin{tabular}{|c|c|c|c|c|c|c|c|c|c|c|}
\hline $\begin{array}{l}\text { Mixture } \\
\text { (wt\% Ta) }\end{array}$ & $\begin{array}{l}\mathrm{Ta} \\
(\mathrm{v} \%) \\
\end{array}$ & $\begin{array}{l}\mathrm{p}^{*} \\
(\%)\end{array}$ & $\begin{array}{l}\text { Ultimate } \\
(\mathrm{MPa})\end{array}$ & $\begin{array}{l}\text { Tensile } \\
\text { (psi) }\end{array}$ & $\begin{array}{l}\text { Strength } \\
\text { (No.)** }\end{array}$ & $(\mathrm{MPa})$ & $\begin{array}{l}\text { ic Modu } \\
\left(10^{6} \mathrm{psi}\right)\end{array}$ & $\begin{array}{l}\mathrm{S} \\
(\mathrm{No} .) * *\end{array}$ & $\begin{array}{c}\mathrm{CTE}^{\dagger} \\
\left(10^{-6}\right) / \mathrm{K} \\
\end{array}$ & $\begin{array}{c}\text { Total } \\
\text { Strain } \\
(\%)\end{array}$ \\
\hline 100 & 100 & 8.0 & 62 & 8,900 & 11 & 65,000 & 9.4 & 11 & $6.2 \pm 0.7$ & 0.1 \\
\hline 95 & 75 & 10.0 & 36 & 5,200 & 7 & 42,000 & 6.1 & 6 & $10.9 \pm 1.2$ & 0.09 \\
\hline 81 & 60 & 7.3 & 23 & 3,300 & 7 & 115,000 & 17. & 6 & $11.1^{\infty}$ & 0.03 \\
\hline 51 & 35 & 10.3 & 19 & 2,800 & 7 & 81,000 & 12. & 7 & $9.3^{\infty}$ & 0.03 \\
\hline
\end{tabular}

*Open porosity

**Number of samples

TCoefficient of thermal expansion

${ }^{\infty}$ One measurement only 


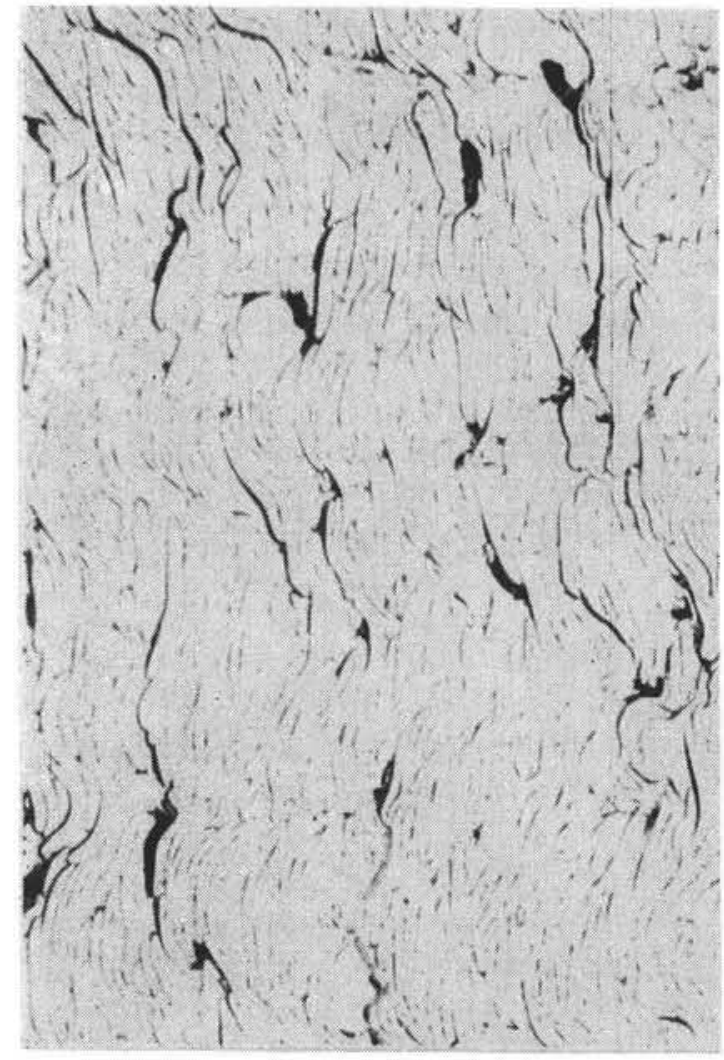

$100^{\prime} \mathrm{v} \% \mathrm{Ta}$.

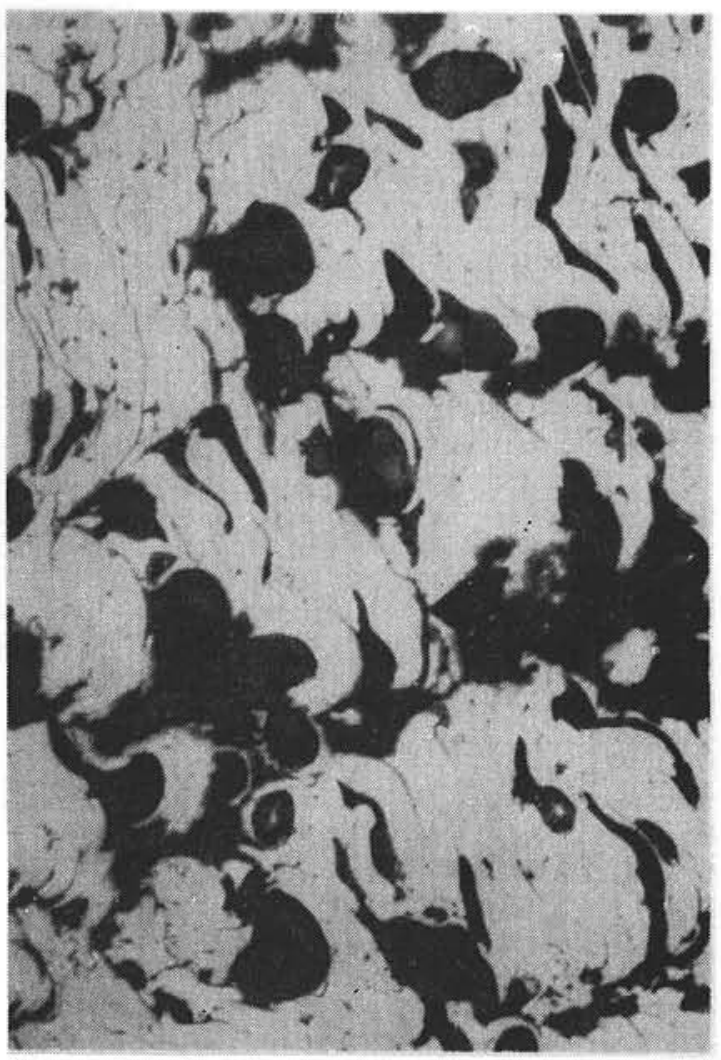

$75 \mathrm{v} \% \mathrm{Ta}$

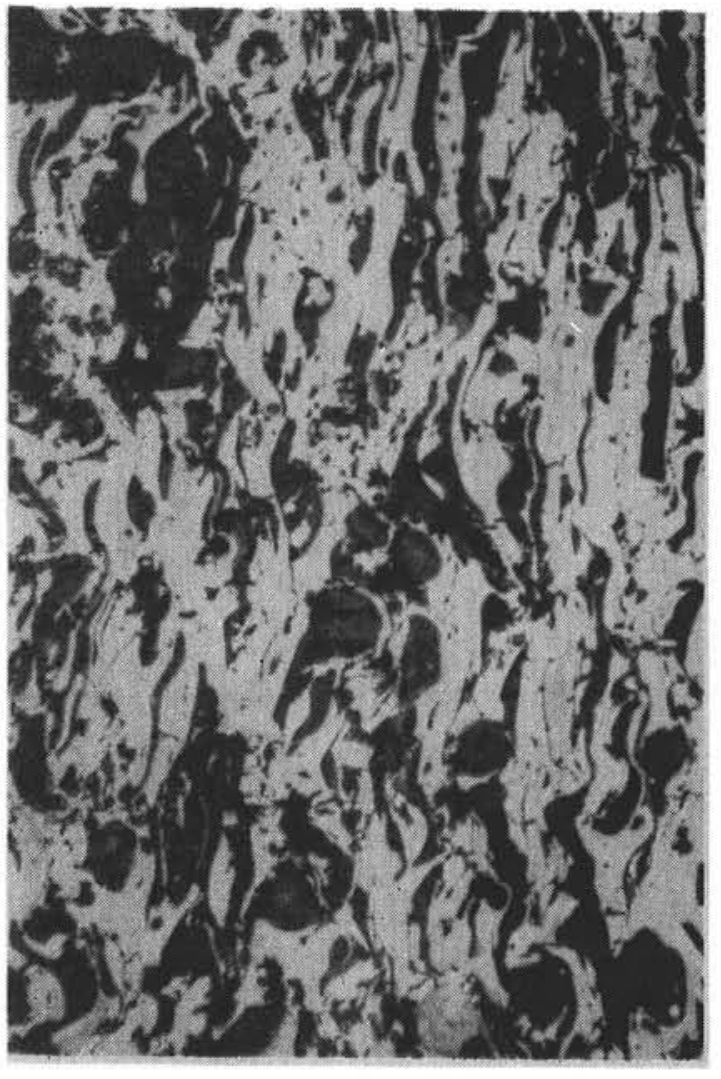

$60 \mathrm{v} \% \mathrm{Ta}$

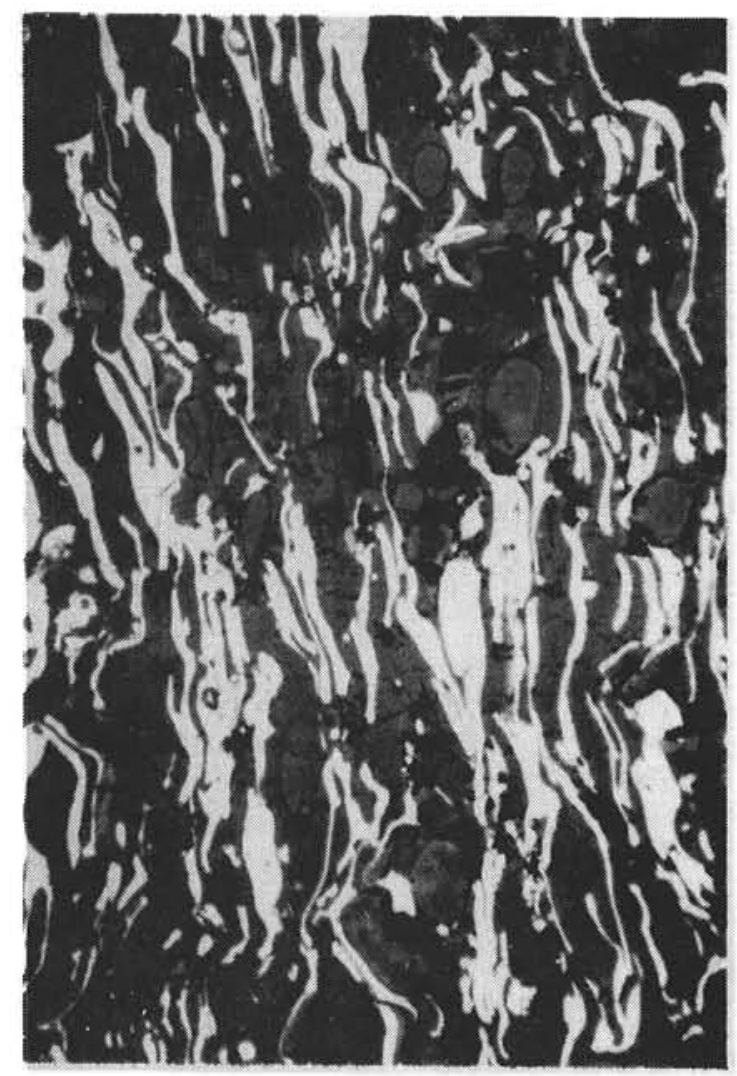

$35 \mathrm{v} \% \mathrm{Ta}$

Figure 7. Cross-Section Photomicrographs of the Four Samples of $\mathrm{Ta}_{\mathrm{a}} / \mathrm{Al}_{2} \mathrm{O}_{3}$ Cermets 
phase, but no reaction between the metal (white phase) and ceramic (grey phase) is apparent. Much of the alumina phase is globular, indicative of partial solidification at the time of impact, and some agglomeration of the alumina is evident as a result of the poor flow character of the powder. Aggregation and partial solidification probably caused the porosity in the vicinity of the ceramic phase. Larger pores were observed in the samples containing greater amounts of alumina.

The wet chemical analysis showed that the $\mathrm{Ta} / \mathrm{Al}_{2} \mathrm{O}_{3}$ ratio could be reproduced within 2 wt\% Ta. Tantalum oxide $\left(\mathrm{Ta}_{2} \mathrm{O}_{5}\right)$ was detected by $\mathrm{X}$ rays. It was concluded that the tantalum powder gettered the residual oxygen in the argon atmosphere of the glove box since the relative amount of $\mathrm{Ta}_{2} \mathrm{O}_{5}$ was less for the last layers of the high tantalum samples. Presumably the $\mathrm{Ta}_{2} \mathrm{O}_{5}$ was a crust on each splat of tantalum. Gamma-alumina was detected in all cermets. The gamma phase, which is a weaker, metastable, less dense form than the alpha-alumina, ${ }^{8}$ has also been observed in plasma-sprayed $\mathrm{Al}^{-\mathrm{Al}_{2}} \mathrm{O}_{3} \cdot{ }^{9}$ Alpha-alumina observed on the upper surfaces of the cermets indicates that slower cooling was occurring on the upper surface, away from the thermally conductive aluminum substrate. The thermal gradient and differential cooling rate probably caused the buildup of residual stresses ${ }^{10}$ that were evidenced by the curvature of the samples. Examination of the fracture surfaces of the tensile specimens revealed inter- and intra-particle separation. Both the alumina and tantalum splats were fractured in Figure 8a. Figure 8b shows that fracture propagated 


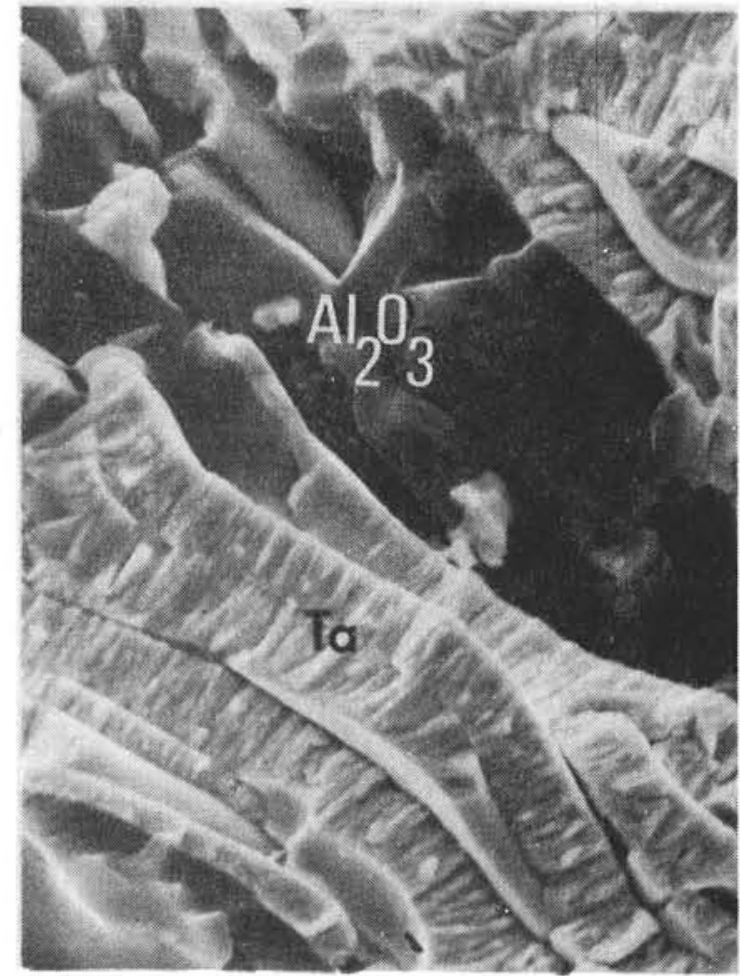

a

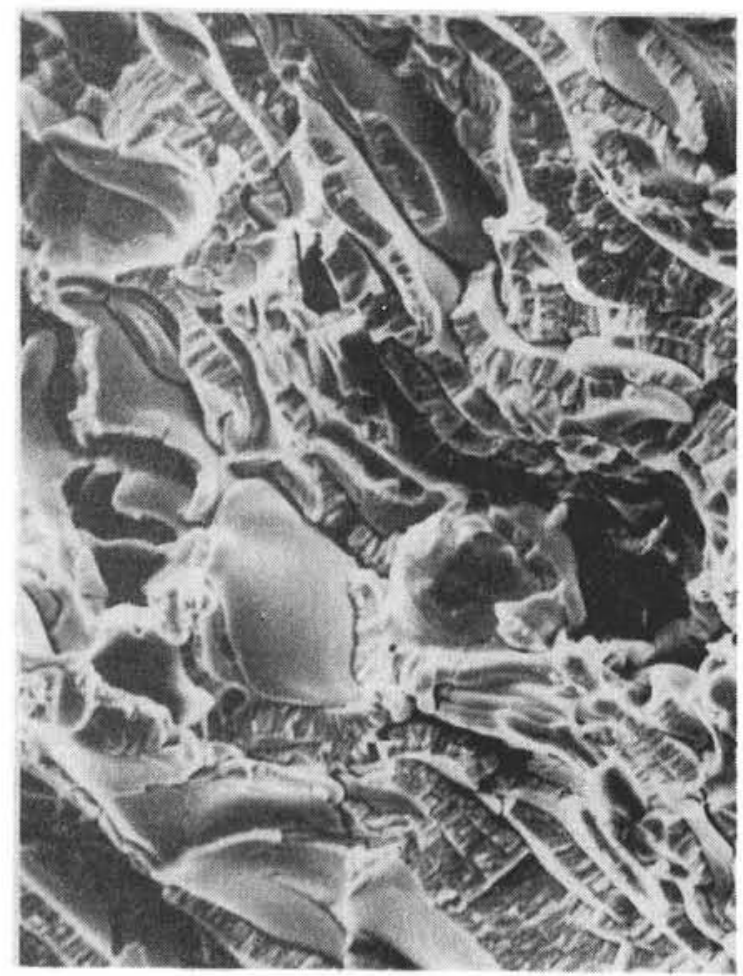

C

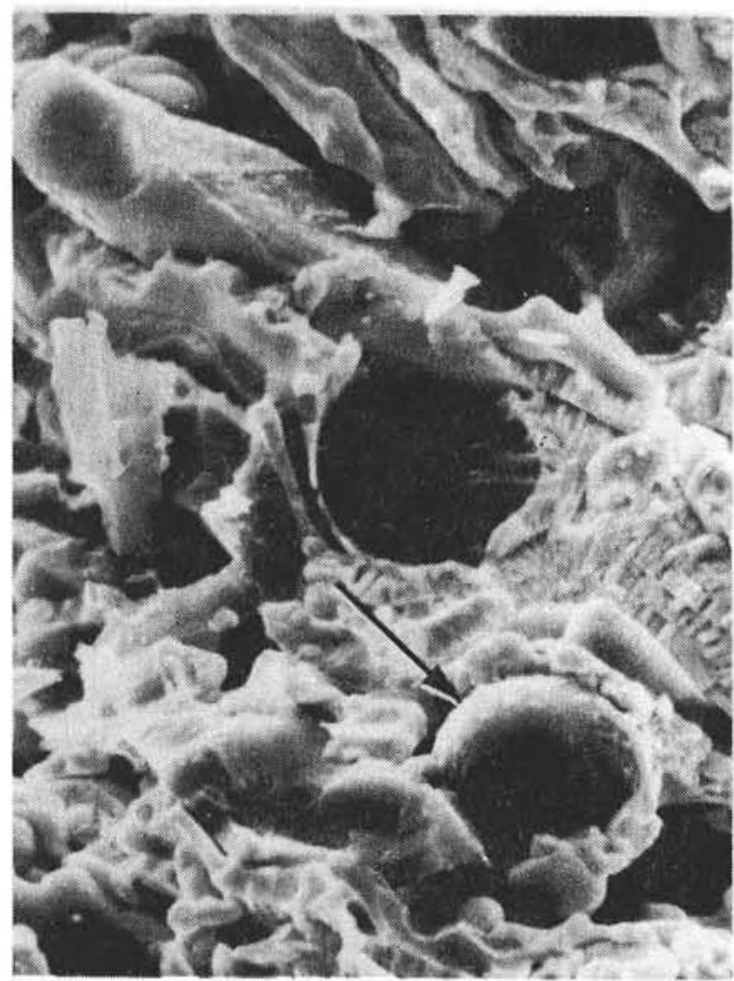

b

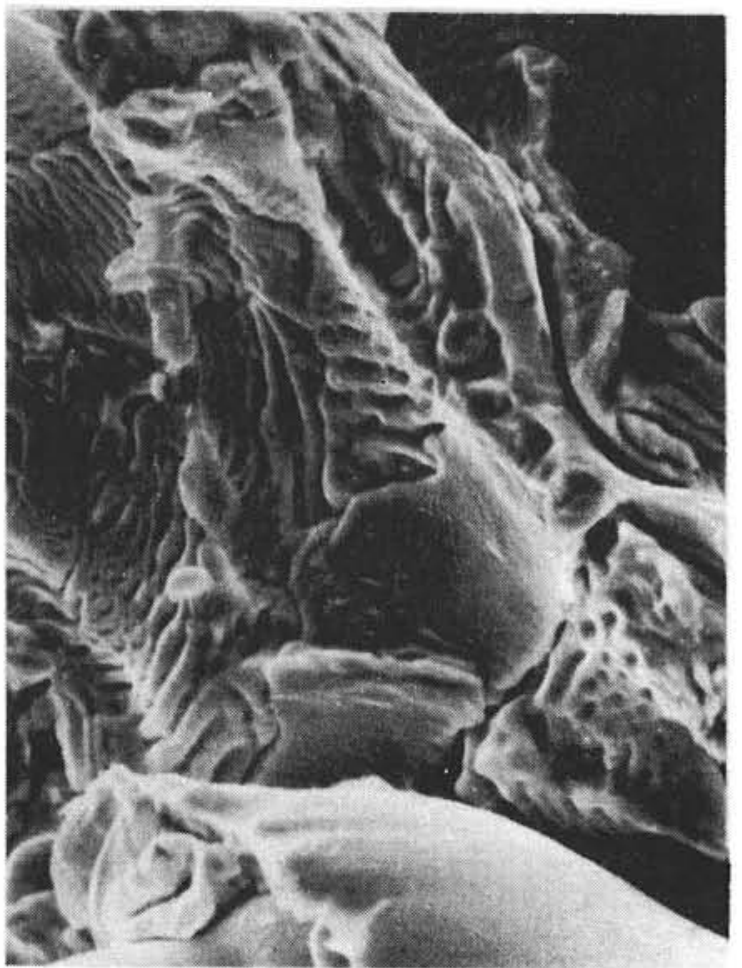

d

Figure 8. Fracture Surfaces of Cermets of $\mathrm{Ta} / \mathrm{Al}_{2} \mathrm{O}_{3}$ Illustrating Intra- and Inter-particle Fracture in Both Phases 
around some spherical particles, which are probably the harder alpha-. alumina phase. Like other multiphase materials having a harder dispersed phase, the alpha-alumina will divert cracks, while the presence of the weaker gamma-alumina allows cracks to progress undiverted. Some separation occurred along the microcracks, which are a result of cooling stresses incurred during, fabrication (Figure $8 \mathrm{c}$ ). Figure $8 \mathrm{~d}$ shows the tracks of the cooling front progression into the metal particles. These observations and those on the magnitudes of the mechanical properties may be notably different for material tested parallel to the spraying direction.

The ultimate tensile strength of the cermets decreased with increasing alumina content from $62 \mathrm{MPa}$ for 100 percent $\mathrm{Ta}$ to $19 \mathrm{MPa}$ for 35 percent Ta. The scatter in the data was large (see Figure 4). All the specimens broke in the gauge section; however, most broke at the extreme end of the reduced section, where stress concentrations are developed during machining. Those specimens that did break in the center of the tensile bar did not exhibit significantly different strengths.

In Table IV pertinent mechanical properties from the literature, including the results of this study, are summarized. Values for tensile strength are much higher for annealed tantalum sheet. The values obtained in Reference 5 compare most closely to those in the present study, since this author and Abbatiello used identical systems and powder. The relation 
MECHANICAL PROPERTIES OF SAMRLES FROM THE LITERATURE AND THIS STUDY

\begin{tabular}{|c|c|c|c|c|}
\hline \multicolumn{5}{|c|}{ TANTALUM } \\
\hline Source & $\begin{array}{l}\text { Ultimate Tensile Strength } \\
\qquad \begin{array}{ll}(\mathrm{MPa}) & \text { (psi) }\end{array}\end{array}$ & $\begin{array}{c}\text { Elastic Modulus } \\
(\overline{\mathrm{MPa}}) \\
\end{array}$ & $\begin{array}{l}\text { Coefficient of } \\
\text { Thermal Expansion }\end{array}$ & $\begin{array}{c}\text { Porosity } \\
(\%)\end{array}$ \\
\hline Ref. $11^{a}$ & 50,000 & $27\left(10^{6}\right)$ & \multirow{3}{*}{$7.7\left(10^{-6}\right) / \mathrm{K}$} & \multirow[b]{4}{*}{12} \\
\hline Ref. $12^{\mathrm{a}}$ & $\begin{array}{cr}193 & 28,000 \\
(0.0 \text { at. } \% \text { oxygen })\end{array}$ & $\begin{array}{c}193,000 \quad 25.7\left(10^{6}\right) \\
(0.0 \text { at. } \% \text { oxygen })\end{array}$ & & \\
\hline Ref. 12 & $\begin{array}{c}882 \quad 128,000 \\
(1.5 \text { at. } \% \text { oxygen })\end{array}$ & $\begin{array}{c}192,000 \text { 27. } 9\left(10^{6}\right) \\
(2.5 \text { at. \% oxygen) }\end{array}$ & & \\
\hline Ref. $5^{b}$ & $\begin{array}{l}48 \quad 7,040 \\
(99.7 \% \mathrm{Ta})\end{array}$ & 4. $6\left(10^{6}\right)$ & 7. $0\left(10^{-6}\right) / \mathrm{K}$ & \\
\hline This study ${ }^{b}$ & 8,900 & $9.4\left(10^{6}\right)$ & $6.2\left(10^{-6}\right) / \mathrm{K}$ & 8 \\
\hline \multicolumn{5}{|c|}{ ALUMINA } \\
\hline Ref. $13^{\mathrm{d}}, 14$ & ${ }^{37}\left(\gamma-\mathrm{Al}_{2} \mathrm{O}_{3}\right)^{5,300}$ & $\begin{array}{c}43,000 \quad 6.3\left(10^{6}\right) \\
(0.3 \text { to } 2.8 \% \text { porosity) }\end{array}$ & 7. $0\left(10^{-6}\right) / \mathrm{K}$ & 8.7 \\
\hline Ref. $15^{\mathrm{e}}$ & $\begin{array}{c}172 \quad 25,000 \\
\left(\alpha-\mathrm{Al}_{2} \mathrm{O}_{3}\right) \\
(3.3 \% \text { porosity })\end{array}$ & $\begin{array}{l}414,000 \quad 60.0\left(10^{6}\right) \\
(0.2 \% \text { porosity })\end{array}$ & $\begin{array}{l}\text { 4. } 7\left(10^{-6}\right) / \mathrm{K} \\
(2 \% \text { porosity) }\end{array}$ & \\
\hline $\begin{array}{l}a_{\text {annealed sheet }} \\
b_{\text {plasma-sprayed }} \\
{ }^{c} 0^{\circ} \text { to } 1000^{\circ} \mathrm{C}\end{array}$ & $\begin{array}{l}d_{\text {flame sprayed (oxy }} \\
e_{\text {sintered alumina }}\end{array}$ & cetylene) alumina rod & & \\
\hline
\end{tabular}


of Duckworth $^{16}$ and the data from this study and that of Abbatiello were used to compute the values of constants $\sigma_{0}$ and $b_{1}$ for plasma-sprayed tantalum to normalize the mechanical properties with respect to porosity.

$$
\begin{aligned}
& \sigma_{\mathrm{P}}=\sigma_{0} \exp \left(-\mathrm{b}_{1} \mathrm{P}\right) \\
& \sigma_{\mathrm{P}}=103 \mathrm{MPa} \cdot \exp (-6.4 \mathrm{P})
\end{aligned}
$$

where

$$
\begin{aligned}
& P=\text { porosity } \\
& \sigma=\text { tensile strength }
\end{aligned}
$$

Values for $b_{1}$ in the literature average about 10 . At zero porosity plasmasprayed tantalum has one-third to one-half the tensile strength of tantalum prepared by conventional methods. Oxide layers or dissolved oxygen in the tantalum reduce the strain to failure and embrittle the material; ${ }^{11,12}$ both of these phenomena are probably occurring in this system. The plasma spray process produces microcracks in the metal structure that are not present in conventionally formed tantalum; this accounts for the low value of $\sigma_{0}$ compared to annealed sheet.

The stress-strain curves of the tantalum and tantalum/alumina did not exhibit perfect elastic behavior. A small deviation from linearity was seen. Young's moduli measured in the elastic region of cermet behavior did not reveal any one trend (probably due in part to residual stresses) as had the tensile strength with respect to composition before normalization with respect to porosity. The values measured in conventionally processed 
tantalum or alumina were much higher; this may be accounted for by the highly defective structure of plasma-sprayed material. The average values of this study (illustrated in Figure 3) and those of Abbatiello for Ta were used in the relationship of Spriggs ${ }^{16}$ [Equation (2)] for the elastic modulus of porous materials, which is analogous to Equation (1).

$$
E_{P}=E_{0} \cdot \exp \left(-b_{2} P\right)
$$

where

$$
\mathrm{E}=\text { Young's modulus }
$$

For plasma-sprayed tantalum this relationship is

$$
E_{P}=268,000 \mathrm{MPa} \cdot \exp (-17.7 \mathrm{P})
$$

This value of $\mathrm{b}_{2}$ is three times that observed for other materials, and $\mathrm{E}_{0}$ is relatively close to that measured for tantalum sheet.

If these values of $b_{1}$ and $b_{2}$ are used for the cermets, $E_{0}$ and $\sigma_{0}$ for each composition may be calculated as in Table V. Presence of alphaalumina greatly raised the elastic moduli of the cermets to values similar to those for the sintered alumina. Normalized values for the metal-rich cermets and pure tantalum are higher than the values reported for annealed tantalum sheet, indicating the effect of the stiffer crust of oxide on the metal particles, and probable solution of oxygen in the tantalum.

Normalized values for the tensile strengths of the high alumina cermets compare well with those for flame-sprayed alumina. This illustrates how the alumina dominates the tensile strength for 60 volume percent metal or less. The total strain exhibited a downward trend as the volume percent of tantalum was reduced below $75 \mathrm{v} \%$. 
TABLE V

NORMALIZED MECHANICAL PROPERTIES OF Ta/Al ${ }_{2} \mathrm{O}_{3}$ CERMETS

\begin{tabular}{ccccc}
\hline Mixture & $\begin{array}{c}\mathrm{Ta} \\
(\mathrm{v} \%)\end{array}$ & $\begin{array}{c}\text { Open Porosity } \\
(\%)\end{array}$ & $\begin{array}{c}\mathrm{E}_{0} \\
(\mathrm{MPa})\end{array}$ & $\begin{array}{c}\sigma_{0} \\
(\mathrm{MPa})\end{array}$ \\
\hline 100 & 100 & 8.0 & 268,000 & 103 \\
95 & 75 & 10.0 & 247,000 & 68 \\
81 & 60 & 7.3 & 419,000 & 37 \\
51 & 35 & 10.3 & 501,000 & 37 \\
\hline
\end{tabular}


The thermal expansion of plasma-sprayed tantalum in this study was similar to the values given in the literature for conventionally prepared tantalum. No definite trends were observed with compositions for the expansion coefficients of the cermets. Probably there were annealing processes occurring during the thermal expansion tests which altered the results. The anomalous rise and fall of the expansion coefficients with increasing alumina cannot be explained. It is believed that the most reliable expansion data is for the 100 percent plasma-sprayed tantalum sample.

\section{Conclusions}

This study showed that the properties of plasma-sprayed cermets can be tailored by powder and process parameter choice. The tensile strength of tantalum/alumina cermets increased from $19 \mathrm{MPa}$ for $35 \mathrm{v} \%$ $\mathrm{Ta}$ to $62 \mathrm{MPa}$ for $100 \mathrm{v} \% \mathrm{Ta}$. The metal increased the total strain to failure. Inter- and intra-particle fracture was observed for both phases. Normalization of the mechanical properties with respect to porosity is necessary to reveal significant trends with respect to composition. 


\section{REFERENCES}

1. R. D. Kremith, J. W. Rosenberry, and V. Hopkins, "Solid Lubricant Coatings Applied by Plasma Spray," Bull. Amer. Ceram. Soc. 47, 9 (1968), p. 813 .

2. D. A. Gerdeman and N. L. Hecht, Arc Plasma Technology in Materials Science (Springer-Verlag, New York, 1972).

3. R. F. Smart and J. A. Catherall, Plasma Spraying (Mills and Boon, Ltd., London, 1972).

4. F. L. Jones, S. R. Elkins, B. Wilkins, and E. S. Barland, "Arc Plasma Coatings for Refractory Metals, "Refractory Metals and Alloys III: Applied Aspects, (Gordon and Breach, New York, 1963), p. 707 .

5. Private communication with Leonard Abbatiello, Y-12 Division, Union Carbide, Oak Ridge, Tennessee.

6. C. W. Andrews and B. A. Fuller, "The Effects of Substrate Materials and Powder Type on the Properties of Plasma-Sprayed Ferrite, " J. Mat. Sci., 10 (1975), p. 1771 .

7. A. R. Stetson and C. A. Hauck, "Plasma Spraying Techniques for Toxic and Oxidizable Materials, " J. Met., 7, (1961), p. 479. 
8. Alumina as a Ceramic Material, (Amer. Ceram. Soc., Columbus, Ohio, 1970) ed. W. H. Gitzen.

9. H. Kellerer and B. Looman, "Experiments for the Preparation of Al- $\mathrm{Al}_{2} \mathrm{O}_{3}$ Dispersion Alloys by Means of Plasma Spray, "Metall. 22, 3. (1968), p. 212 .

10. W. E. Stanton, "Contraction Stresses in Sprayed Metal Deposits," Met. Ind., 12, (1958), p. 509.

11. Metals Handbook 1 (Amer. Soc. Met., Metals Park, Ohio, 1961).

12. G. L. Miller, Tantalum and Niobium (Academic Press, New York, 1959).

13. N. N. Ault, "Characteristics of Refractory Oxide Coatings Produced by Flame-Spraying," J. Amer. Ceram. Soc., 40, 3 (1957), p. 69.

14. M. Bartuska, "Plasma Torch Spraying of Refractory Coatings from Oxides and Compounds, "Strojirenstiv, 23, (11), (1973), p. 675.

15. Engineering Properties of Selected Ceramic Materials, (Amer. Ceram. Soc., Columbus, Ohio, 1966).

16. Chemical and Mechanical Behavior of Inorganic Materials, (Wiley Interscience, New York, 1970), ed. A. W. Searcy, D. V. Dagme, and U. Colombo, p. 405. 
UNLIMITED RELEASE

INITIAL DISTRIBUTION:

Z. A. Munir

Department of Mechanical Engineering

University of California

Davis, CA 95616

R. M. German

Mott Metallurgical Corporation

P. O. Drawer I

Farmington, CT 06032

R. S. Claassen, 5800

M. J. Davis, 5830

T. V. Nordstrom, 5833

R. J. Eagan, 5845

E. K. Beauchamp, 5846

T. B. Cook, Jr., 8000; Attn: A. N. Blackwell, 8010

C. H. DeSelm, 8200

L. Gutierrez, 8100

W. C. Scrivner, 8400

G. W. Anderson, 8140

B. F. Murphey, 8300

D. M. Schuster, 8310

D. R. Adolphson, 8312

Pete Oliver, 8312 (3)

J. E. Smugeresky, 8312

J. J. Bartel, 8313

C. M. Kramer, 8313 (10)

R. W. Mar, 8313

W. R. Hoover, 8314

A. J. West, 8314

L. A. West, 8315

J. Wirth, 8340

F. J. Cupps, 8265/Technical Library Processes Division, 3141

Technical Library Processes Division, 3141 (2)

Library and Security Classification Division, 8266-2 (3)

Technical Publications and Art Division, 8265, for TIC (2) 